\title{
Tinjau Ulang Nilai Faktor Penduga dan Rumus Diskriminan untuk Mendiagnosis Hipertiroid pada Mola Hidatidosa
}

\author{
Nanny Natalia Mulyani Soetedjo, Sri Hartini KS Kariadi \\ Departemen Ilmu Penyakit Dalam \\ Fakultas Kedokteran Universitas Padjadjaran-Rumah Sakit Hasan Sadikin
}

\begin{abstract}
Abstrak
Penatalaksanaan mola hidatidosa hanya dengan suction curretage dapat mencetuskan krisis tiroid pada penderita hipertiroid klinis maupun subklinis. Penelitian sebelumnya menemukan bahwa frekuensi nadi $\geq 100 \mathrm{kali} / \mathrm{menit}$, tinggi fundus uteri $\geq 20$ minggu, dan kadar complete $\mathrm{hCG} \geq 300.000 \mathrm{uIU} / \mathrm{mL}$ merupakan faktor penduga untuk diagnosis hipertiroid pada mola hidatidosa. Rumus diskriminan digunakan pada keadaan tidak didapatkan faktor penduga tersebut. Tujuan penelitian ini adalah meninjau ulang nilai faktor penduga dan rumus diskriminan untuk mendiagnosis hipertiroid pada penderita mola hidatidosa. Subjek penelitian adalah penderita mola hidatidosa yang dirawat di RS Hasan Sadikin Bandung periode tahun 2006-2008. Uji statistik menggunakan uji chi-square atau Fisher's exact, dan uji Pearson atau Spearman. Usia rata-rata 95 kasus mola hidatidosa adalah 28,12+8,24 tahun, 79 kasus $(83,2 \%)$ mempunyai kadar TSH $<0,3 \mathrm{uIU} / \mathrm{mL}$. Mempergunakan uji Fisher's exact hanya didapatkan frekuensi nadi $\geq 100 \mathrm{kali} /$ menit yang mempunyai hubungan signifikan dengan hipertiroid $(\mathrm{p}=0,000 ; \mathrm{p}<0,05)$, Merpergunakan uji Fisher's exact didapatkan pada kelompok frekuensi nadi $<100 \mathrm{kali} / \mathrm{menit}$ dengan rumus diskriminan positif, mempunyai hubungan signifikan dengan hipertiroid $(p=0,017 ; p<0,05)$. Mempergunakan uji Spearman didapatkan frekuensi nadi/menit dan kadar $\beta$ hCG yang mempunyai hubungan signifikan $(p=0,000$ dan $\mathrm{p}=0,004 ; \mathrm{p}<0,05)$. Kesimpulan frekuensi nadi $\geq 100 \mathrm{kali} /$ menit dapat digunakan sebagai faktor penduga hipertiroid pada penderita mola hidatidosa. Pada penderita mola hidatidosa yang mempunyai frekuensi nadi $<100 \mathrm{kali} / \mathrm{menit}$, maka rumus diskriminan dapat dipakai untuk menduga hipertiroid. [MKB. 2011;43(1):35-41].
\end{abstract}

Kata kunci: Frekuensi nadi, hipertiroid, mola hidatidosa, rumus diskriminan

\section{Re-review of Predictive Value and Discriminant Formula for Diagnosis Hyperthyroid in Mole Hydatidiform}

\begin{abstract}
The only treatment for mole hydatidiform patients is by suction curretage and this procedure can make thyroid storm in patient with clinical or subclinical hyperthyroid. They found that heart rate $\geq 100$ beats per minute, uterus height $\geq 20$ weeks, and $\beta h C G$ levels $\geq 300,000 \mathrm{uIU} / \mathrm{mL}$ can be used as predictive value to diagnose hyperthyroid in mole hydatidiform patients. While discriminant formula can be used whether there were no those predictive values. The aim in this study was to see again whether predictive value and discriminant formula can be used to diagnose hyperthyroid in mole hydatidiform patients. Mole hydatidiform patients between 2006-2008 in Hasan Sadikin Hospital Bandung were entered in this study. Chi-square or Fisher's exact test was using in this study and also Pearson or Spearman test. Means of 95 mole hydatidiform patients aged in this study was $28.12 \pm 8.24$ years old, 79 patients $(83,2 \%)$ had hyperthyroid with TSH level $<0.3 \mathrm{uIU} / \mathrm{mL}$. Only heart rate had significant association ( $\mathrm{p}$ value $0.000(\mathrm{p}<0.05))$ with hyperthyroid by using Fisher's exact test. With Fisher's exact test, only heart rate $<100$ beat per minute with positive discriminant formula had association with hyperthyroid with $p$ value 0.017 $(\mathrm{p}<0.05)$, but not if they had uterus height $<20$ weeks. As conclusion that only heart rate $\geq 100$ beats per minute can be used to predict hyperthyroid in mole hydatidiform patients. If mole hydatidiform patient has heart rate $<100$ beats per minute we can use discriminant formula to predict hyperthyroid. [MKB. 2011;43(1):35-41].
\end{abstract}

Key words: Discriminant formula, heart rate, hyperthyroid, mole hydatidiform

Korespondensi: Nanny Natalia Mulyani Soetedjo, dr., Sp.Pd-KEMD., M.Kes., DCN, Departemen Ilmu Penyakit Dalam Fakultas Kedokteran Universitas Padjadjaran-Rumah Sakit Hasan Sadikin, jalan Pasteur 38 Bandung, mobile (022) 2033274 


\section{Pendahuluan}

Pada penderita mola hidatidosa sering terjadi hipertiroidyang prevalensinyabervariasi. Chiniwala dkk. ${ }^{1}$ mendapatkan prevalensi hipertiroid $25-64 \%$, sedangkan menurut Berkowitz dan Golstein ${ }^{2,3}$ hanya 7\%. Kariadi, ${ }^{4}$ Riastuti, ${ }^{5}$ serta Soetedjo dan Kariadi ${ }^{6}$ mendapatkan prevalensi hipertiroid pada mola hidatidosa berturut-turut sebanyak 78,8\%, $74,5 \%$, dan $72,4 \%$. Keadaan hipertiroid pada mola hidatidosa sukar untuk dikenali, karena biasanya asimtomatis (subklinis). Satu-satunya yang dapat digunakan sebagai diagnosis pasti adalah kadar thyroid stimulating hormone (TSH) yang rendah. Pemeriksaan hormon ini tidak dapat dilakukan segera dan memerlukan biaya yang mahal. $^{7}$

Penatalaksanaan mola hidatidosa hanya dengan evakuasi jaringan mola. Suction curretage merupakan metode utama pada mola hidatidosa. Histerektomi (pengangkatan seluruh rahim) dilakukan pada mola invasif atau pada penderita mola berusia di atas 40 tahun karena risiko rekurensinya tinggi. Pada keadaan hipertiroid, tindakan evakuasi ini dapat menjadi pencetus terjadinya krisis tiroid. ${ }^{2,8,9}$ Ada satu kasus yang dilaporkan Malye dkk. ${ }^{10}$ bahwa penderita mola hidatidosa mengalami krisis tiroid disertai acute respiratory distress syndrome (ARDS) setelah tindakan evakuasi dengan suction curretage.

Pada penderita mola hidatidosa didapatkan penanda tumor yang meningkat, yaitu human chorionic gonadotrophin (HCG). ${ }^{11}$ Penanda ini merupakan hormon glikoprotein yang diproduksi oleh jaringan trofoblas dan merupakan penanda kehamilan serta penyakit trofoblastik kehamilan. ${ }^{12}$ Golongan hormon glikoprotein lainnya adalah luteinezing hormone (LH), follicle stimulating hormone (FSH), dan thyroid stimulating hormone (TSH). Semua hormon glikoprotein terdiri atas heterodimer yang mengandung sebuah subunit $\alpha$ dan sebuah subunit $\beta .^{13}$

Karena HCG dan TSH merupakan golongan hormon glikoprotein, keduanya mempunyai struktur yang sama pada fragmen subunit $\beta$, maka dengan HCG serum yang meningkat akan berikatan di reseptor TSH, sehingga HCG bertindak seolaholah seperti TSH yang meningkatkan aktivitas hormon tiroid. Akibatnya TSH akan tertekan dan menurun kadarnya. Hal ini berbeda dengan penyakit tiroid autoimun (seperti penyakit Graves) terdapat autoantibodi (TSAb) yang berkompetitif dengan TSH untuk berikatan dengan reseptor TSH, sehingga bila antibodi ini berikatan akan meningkatkan akumulasi cAMP yang menyebabkan pembesaran kelenjar tiroid (goiter) dan tanda-tanda hipertiroid secara klinis. ${ }^{14,15}$ Korelasi antara kadar HCG dan beratnya derajat metabolik hipertiroid adalah 25.000 U/L HCG setara dengan $1 \mathrm{mU} / \mathrm{L}$ aktivitas TSH. ${ }^{16}$

Untuk membedakan mola hidatidosa dengan kehamilan normal dapat dengan melihat perbedaan kadar HCG total di dalam darah. Van Trommel dkk. ${ }^{12}$ melakukan penelitian untuk melihat apakah total $\mathrm{HCG}, \beta \mathrm{HCG}, \alpha \mathrm{HCG}$ atau ratio antara $\beta$ HCG dan HCG total dapat membedakan kehamilan normal dengan penyakit trofoblastik kehamilan. Hasil penelitian ini membuktikan bahwa dengan mengukur kadar $\beta$ HCG yang meningkat saja dapat membedakan keduanya. ${ }^{2}$ Cole dkk. ${ }^{17}$ menemukan bahwa kadar free$\beta H C G$ sendiri dapat digunakan sebagai salah satu penanda untuk monitoring mola hiatidosa yang akan menjadi placental site trophoblastic tumor.

Beberapa penelitian sebelumnya telah berusaha untuk mencari faktor penduga yang dapat dijadikan penanda adanya hipertiroid. Pada tahun 1992 Kariadi $^{4}$ menemukan frekuensi nadi $\geq 100 \mathrm{kali} / \mathrm{menit}$, tinggi fundus uteri $\geq 20$ minggu, dan kadar complete HCG $>300.000$ $\mathrm{uIU} / \mathrm{mL}$ merupakan penanda kuat terdapatnya tirotoksikosis pada penderita mola hidatidosa, selain itu juga ditetapkan rumus diskriminan yang dapat digunakan sebagai penanda keadaan tirotoksikosis.

Riastuti $^{5}$ melakukan tinjau ulang pada penderita mola hidatidosa tahun 1996-1998 dan menemukan hal yang sama dengan Kariadi, yaitu frekuensi nadi $\geq 100 \mathrm{kali} / \mathrm{menit}$ dan tinggi fundus uteri $\geq 20$ minggu merupakan penanda kuat adanya tirotoksikosis pada penderita mola hidatidosa. Rumus diskriminan tidak dapat digunakan sebagai penanda kuat tirotoksikosis, tetapi pada keadaan tidak adanya penanda kuat (frekuensi nadi $<100 \mathrm{kali} /$ menit dan tinggi fundus uteri $<20$ minggu) ternyata rumus diskriminan yang positif dapat digunakan sebagai penanda tirotoksikosis. ${ }^{5}$ Pada tahun 2007, Soetedjo dan Kariadi $^{6}$ mendapatkan hanya frekuensi nadi $\geq 100$ kali/menit dapat dipakai sebagai faktor penduga tirotoksikosis, sedangkan rumus diskriminan tetap dapat dipakai sebagai faktor penduga tirotoksikosis pada frekuensi nadi $<100 \mathrm{kali} / \mathrm{menit}$ dan tinggi fundus uteri $<20$ minggu. Kesamaan ketiga penelitian ini adalah pemeriksaan kadar complete $\mathrm{HCG}$ dan $\beta \mathrm{HCG}$ dilakukan di Bagian Kedokteran Nuklir RS. Hasan Sadikin Bandung dengan menggunakan metode immunoradiometric assay (IRMA) (untuk kadar complete HCG pada penelitian oleh Kariadi ${ }^{4}$ tahun 1992) dan radioimmunoassay (RIA) (untuk kadar $\beta$ HCG pada penelitian Riastuti ${ }^{5}$ serta Soetedjo dan Kariadi $^{6}$ ). Mulai tahun 2006 pemeriksaan kadar $\beta H C G$ dilakukan di bagian Patologi Klinik RS. Hasan Sadikin Bandung dengan menggunakan metode electrochemilum-inescence immunoassay 
(ECLIA), sedangkan untuk pemeriksaan fungsi tiroid dilakukan di Departemen Kedokteran Nuklir Fakultas Kedokteran Universitas PadjadjaranRumah Sakit Hasan Sadikin Bandung.

Tujuan penelitian ini adalah meninjau ulang apakah faktor penduga (frekuensi nadi, fundus uteri, dan kadar $\beta \mathrm{HCG}$ ) serta rumus diskriminan dapat dipergunakan untuk diagnosis hipertiroid pada penderita mola hidatidosa.

\section{Metode}

Subjek adalah penderita mola hidatidosa yang dirawat di RS. Hasan Sadikin Bandung periode tahun 2006-2008. Data diambil dari rekam medis. Kriteria inklusi sebagai berikut: 1) kasus mola hidatidosa yang mempunyai data fungsi tiroid (minimal kadar TSHs), 2) kasus mola hidatidosa yang mempunyai data kadar $\beta \mathrm{hCG}, 3$ ) kasus mola hidatidosa dengan nilai Haemoglobin $(\mathrm{Hb}) \geq 7 \mathrm{~g} / \mathrm{dL}$.

Batasan operasional untuk frekuensi nadi, dikatakan takikardia jika pada perhitungan frekuensi nadi atau denyut jantung $\geq 100 \mathrm{kali} /$ menit. ${ }^{18}$ Kadar $\beta H C G$ dengan metode ECLIA, harga normalnya adalah $<2 \mathrm{uIU} / \mathrm{mL}$ (sebelumnya dengan metode RIA kadar normal $\beta H C G<5$ $\mathrm{uIU} / \mathrm{mL}$ ). Untuk batasan rujukan normal fungsi tiroid (pemeriksaan dilakukan dengan metode RIA) ditetapkan oleh Bagian Kedokteran Nuklir RS. Hasan Sadikin/FK Unpad Bandung, adalah sebagai berikut: TSHs: $0,3-5,0 \mathrm{uIU} / \mathrm{mL}$, fT4: 0,8-1,9 ng/dL, dan T3:1,3-2,9 nmol/L

Hipertiroid terjadi jika penderita mempunyai fungsi tiroid yang tidak normal, yaitu kadar fT4 dan T3 meningkat serta kadar TSHs menurun dari harga normal standar pemeriksaan fungsi tiroid. Pada penelitian ini fungsi hormon yang digunakan adalah TSHs mengingat banyak kasus mola hidatidosa yang mengalami hipertiroid subklinis (kadar T3 dan fT4 normal, tetapi kadar TSHs lebih rendah dari harga normal standar pemeriksaan yang ada. ${ }^{7,19}$

Rumus diskriminan oleh $\mathrm{Kariadi}^{4}$ pada tahun 1992 adalah sebagai berikut:

$\mathrm{D}=-8,37612800+0,52508700 \mathrm{FU}-0,01926897 \mathrm{Nadi}$
(FU: ukuran rahim/tinggi fundus uteri dalam minggu; nadi: frekuensi nadi/menit). $\quad \mathrm{D}<0$ menunjukkan tirotoksikosis pada mola (dengan classification accuracy $87,5 \%) .{ }^{4}$

Penelitian retrospektif ini memakai metode deskriptif analitik. Semua data dikumpulkan dan dicari hubungan yang paling kuat frekuensi nadi, tinggi fundus uteri, kadar $\beta \mathrm{HCG}$, dan rumus diskriminan dengan hipertiroid (kadar TSHs $<0,3$ $\mathrm{uIU} / \mathrm{mL}$ ) dengan uji chi-square, dan jika tidak memenuhi syarat digunakan uji Fisher's exact. Selain itu dilakukan uji korelasi variabel yang ada dengan kadar TSHs menggunakan uji Pearson (jika data berdistribusi normal) dan uji Spearman (jika data tidak berdistribusi normal) dengan tingkat kepercayaan 95\% dan signifikan jika $\mathrm{p}<0,05$.

\section{Hasil}

Selama periode 2006-2008 didapatkan 95 kasus mola hidatidosa dari data rekam medis yang memenuhi kriteria inklusi. Dalam penelitian ini hanya TSHs yang digunakan, karena banyak penderita yang tidak mempunyai data fT4 dan T3. Menurut Bloomgarden ${ }^{7}$ dinyatakan bahwa fungsi tiroid pada kehamilan termasuk mola hidatidosa, cukup dengan memeriksa kadar TSHs.

Karakteristik dasar 95 kasus mola hidatidosa dapat dilihat pada Tabel 1. Pada penderita dengan mola hidatidosa ini didapatkan 79 kasus $(83 \%)$ dengan kadar TSHs $<0,3 \mathrm{uIU} / \mathrm{mL}$ (hipertiroid baik klinis maupun subklinis) dan 16 kasus (17\%) dengan TSHs $>0,3 \mathrm{uIU} / \mathrm{mL}$ (tidak ada hipertiroid). Pada 95 subjek ini didapatkan 43 kasus (45\%) dengan kadar $\beta$ HCG $>300.000 \mathrm{uIU} / \mathrm{mL}, 24$ kasus (25\%) dengan kadar $\beta$ HCG 100.000-300.000 $\mathrm{uIu} / \mathrm{mL}$, dan 28 kasus (30\%) dengan kadar $\beta \mathrm{HCG}$ $<100.000 \mathrm{uIU} / \mathrm{mL}$.

Hubungan frekuensi nadi, tinggi fundus uteri, kadar $\beta H C G$, dan rumus diskriminan dengan kejadian hipertiroid (kadar TSHs $<0,3 \mathrm{uIU} / \mathrm{mL}$ ) dapat dilihat pada Tabel 2 (uji Fisher's exact).

Pada Tabel 2 didapatkan hanya frekuensi nadi $\geq 100 x /$ menit yang mempunyai hubungan

Tabel 1 Karakteristik Dasar Penderita Mola Hidatidosa Tahun 2006-2008

\begin{tabular}{ll}
\hline Variabel & Rata-rata \pm SD / Min-Maks (Median) \\
\hline Jumlah penderita & 95 \\
Usia & $28,12 \pm 8,24$ tahun \\
Frekuensi nadi/menit & $106,7 \overline{8} \pm 13,16 \mathrm{kali} / \mathrm{menit}$ \\
Tinggi fundus uteri & $17,03+4,82 \mathrm{minggu}$ \\
Kadar hemoglobin & $9,49 \pm 1,07 \mathrm{~g} / \mathrm{dL}$ \\
Kadar $\beta \mathrm{HCG}$ & $61->1.000 .000(253.771) \mathrm{uIU} / \mathrm{mL}$ \\
Kadar TSHs & $<0,03-1,5(0,03) \mathrm{uIU} / \mathrm{mL}$ \\
\hline
\end{tabular}


Tabel 2 Hubungan Frekuensi Nadi, Tinggi Fundus Uteri, dan Rumus Diskriminan dengan Hipertiroid (Uji Fisher's Exact)

\begin{tabular}{|c|c|c|c|}
\hline \multirow{2}{*}{ Variabel } & \multicolumn{2}{|c|}{ Kadar TSHs } & \multirow{2}{*}{ Nilai $p$} \\
\hline & $<0,3 \mathrm{uIU} / \mathrm{mL}$ & $\geq 0,3 \mathrm{uIU} / \mathrm{mL}$ & \\
\hline $\begin{array}{l}\text { Frekuensi Nadi } \\
>100 \mathrm{x} / \mathrm{mnt}\end{array}$ & $70(74 \%)$ & $3(3 \%)$ & \multirow{3}{*}{0,000} \\
\hline$<100 x / m n t$ & $9(9 \%)$ & $13(14 \%)$ & \\
\hline Total & $79(83 \%)$ & $16(17 \%)$ & \\
\hline $\begin{array}{l}\text { Tinggi Fundus Uteri } \\
\text { (minggu) }\end{array}$ & & & \multirow{4}{*}{0,135} \\
\hline & $27(28 \%)$ & $2(2 \%)$ & \\
\hline$<20$ & $52(55 \%)$ & $14(15 \%)$ & \\
\hline Total & $79(83 \%)$ & $16(17 \%)$ & \\
\hline \multicolumn{4}{|l|}{ Rumus Diskriminan } \\
\hline $\mathrm{D}<0$ (positif) & $60(63 \%)$ & $14(15 \%)$ & \multirow{3}{*}{0,51} \\
\hline $\mathrm{D}>0$ (negatif) & $\begin{array}{l}00(03 \%) \\
10(20 \%)\end{array}$ & & \\
\hline Total & $19(20 \%)$ & $2(2 \%)$ & \\
\hline
\end{tabular}

Tabel 3 Hubungan Kadar $\beta$ HCG dengan Hipertiroid (Uji Fisher's Exact)

\begin{tabular}{cccc}
\hline \multirow{2}{*}{ Variabel } & \multicolumn{2}{c}{ Kadar TSHs } & \multirow{2}{*}{ Nilai p } \\
\cline { 2 - 3 } & $<\mathbf{0 , 3} \mathbf{~ u I U} / \mathbf{m L}$ & $\mathbf{0 0 , 3} \mathbf{~ I I U} / \mathbf{m L}$ & \\
\hline BHCG $(\mathrm{uIU} / \mathrm{mL})$ & & & \\
$\geq 300.000$ & $39(41 \%)$ & $4(4 \%)$ & 0,1 \\
$<300.000$ & $40(42 \%)$ & $12(13 \%)$ & \\
Total & $79(83 \%)$ & $16(17 \%)$ & \\
$\beta H C G$ & $60(63 \%)$ & $7(7 \%)$ & 0,016 \\
$\geq 100.000$ & $19(20 \%)$ & $9(9 \%)$ & \\
$<100.000$ & $79(83 \%)$ & $16(17 \%)$ & \\
Total & &
\end{tabular}

signifikan dengan hipertiroid (kadar TSHs $<0,3 \mathrm{uIU} / \mathrm{mL})$, dengan nilai $\mathrm{p}=0,000(\mathrm{p}<0,05)$, sedangkan tinggi fundus uteri dan rumus diskriminan tidak mempunyai hubungan yang signifikan $(\mathrm{p}>0,05)$.

Untuk mencari kelompok kadar $\beta$ HCG mana yang mempunyai hubungan signifikan dengan hipertiroid maka dilakukan dengan uji chi-square jika memenuhi syarat dan uji Fisher's exact jika tidak memenuhi syarat uji chi-square (Tabel 3).

Pada Tabel 3 dapat dilihat bahwa pada kelompok kadar $\beta \mathrm{HCG} \geq 100.000 \mathrm{uIU} / \mathrm{mL}$ secara uji Fisher's exact mempunyai hubungan signifikan dengan kadar TSHs $<0,3 \mathrm{uIU} / \mathrm{mL}$ (hipertiroid) $(\mathrm{p}=0,016)$ dibandingkan dengan kelompok kadar $\beta \mathrm{HCG}$ $\geq 300.000 \mathrm{uIU} / \mathrm{mL}$ tidak terdapat hubungan signifikan dengan hipertiroid $(\mathrm{p}=0,1)$.

Pada 22 dari 95 penderita (23\%) tanpa takikardia (frekuensi nadi $<100 \mathrm{kali} / \mathrm{menit}$ ) dilakukan uji chisquare atau Fisher's exact untuk mencari hubungan nilai diskriminannya dengan hipertiroid. Hasil dari perhitungan dapat dilihat pada Tabel 4.

Pada Tabel 4 dapat dilihat dari 22 kasus mola hidatidosa dengan frekuensi nadi $<100 x /$ menit, didapatkan 9 kasus dengan kadar TSHs $<0,3 \mathrm{uIU} / \mathrm{mL}$ (hipertiroid) dan 13 kasus dengan kadar TSHs $\geq 0,3 \mathrm{uIU} / \mathrm{mL}$. Setelah dilakukan uji Fisher's exact didapatkan hubungan signifikan antara rumus diskriminan yang positif $(\mathrm{D}<0)$ dan kejadian hipertiroid (kadar TSHs $<0,3 \mathrm{uIU} / \mathrm{mL}$ )

Tabel 4 Hubungan Rumus Diskriminan dengan Hipertiroid pada Penderita Mola Hidatidosa yang Mempunyai Frekuensi Denyut Jantung <100x/Menit (Uji Fisher's Exact)

\begin{tabular}{cccc}
\hline \multirow{2}{*}{ Rumus Diskriminan } & \multicolumn{2}{c}{ Kadar TSHs } & \multirow{2}{*}{ Nilai $\mathbf{p}$} \\
\cline { 2 - 3 } & $<\mathbf{0 , 3} \mathbf{~ u I U} / \mathbf{m L}$ & $\mathbf{0 , 3} \mathbf{~ u I U} / \mathbf{m L}$ & \\
$\mathrm{D}<0$ (positif) & $5(23 \%)$ & $13(59 \%)$ & \multirow{2}{*}{0,017} \\
$\mathrm{D}>0$ (negatif) & $4(18 \%)$ & $0(0 \%)$ & \\
Total & $9(41 \%)$ & $13(59 \%)$ & \\
\hline
\end{tabular}


Tabel 5 Korelasi TSHs dengan Usia, Frekuensi Nadi, Tinggi Fundus Uteri, dan Kadar $\beta$ HCG pada Penderita Mola Hidatidosa

\begin{tabular}{lcc}
\hline \multicolumn{1}{c}{ Korelasi TSHs dengan } & Nilai r & Nilai p \\
\hline Usia & $-0,114$ & 0,273 \\
Frekuensi nadi & $-0,525$ & 0,000 \\
Tinggi fundus uteri & $-0,144$ & 0,164 \\
Kadar $\beta$ HCG & $-0,294$ & 0,004 \\
\hline
\end{tabular}

$(\mathrm{p}=0,017)$.

Untuk mengetahui kuatnya hubungan antara TSHs dan faktor-faktor lainnya, yaitu usia, frekuensi nadi, tinggi fundus uteri, serta kadar $\beta$ HCG maka dilakukan uji korelasi Spearman (karena data tidak berdistribusi normal). Adapun hasil uji korelasi ini dapat dilihat pada Tabel 5.

Pada Tabel 5 dapat kita lihat bahwa dengan uji Spearman didapatkan hubungan yang signifikan $(\mathrm{p}<0,05)$ adalah kadar TSHs dengan frekuensi nadi dan kadar $\beta H C G$. TSHs dengan frekuensi nadi mempunyai kekuatan korelasi (r) sebesar $-0,525$ yang berarti kekuatan korelasi ini sedang, sedangkan TSHs dengan kadar $\beta$ HCG mempunyai kekuatan korelasi (r) sebesar -0,294 yang berarti kekuatan korelasi ini lemah. Untuk mengetahui hubungan TSHs dengan keduanya (frekuensi nadi dan kadar $\beta$ HCG) maka dilakukan uji regresi linier dengan metode forward. Berdasarkan perhitungan hanya frekuensi nadi yang mempunyai koefisien signifikan dengan $\mathrm{p}=0,000 \quad(\mathrm{p}<0,05)$ dan nilai $\mathrm{F}=26,429$ serta tingkat kepercayaan $95 \%$, maka didapatkan rumus sebagai berikut:

$\mathrm{Y}=1,106-0,009 \mathrm{X} ; \mathrm{Y}=$ kadar TSHs dan $\mathrm{X}=$ frekuensi nadi

\section{Pembahasan}

Pada penelitian ini dari 95 kasus mola hidatidosa didapatkan usia rata-rata $28,12 \pm 8,24$ tahun dengan usia termuda 16 tahun, usia tertua 48 tahun, dan median 26 tahun. Pada penelitian Kariadi ${ }^{4}$ didapatkan median usia dari 33 kasus mola hidatidosa adalah 22 tahun dengan usia termuda 18 tahun dan usia tertua 40 tahun. Pada penelitian Riastuti ${ }^{5}$ dari 51 kasus mola hidatidosa tahun 1996-1998 didapatkan median usia 26 tahun dengan usia termuda 17 tahun dan usia tertua 47 tahun. Pada penelitian Soetedjo dan Kariadi ${ }^{6}$ dari 105 kasus mola hidatidosa tahun 2002-2005 didapatkan median usia 28 tahun dengan usia termuda 16 tahun dan usia tertua 50 tahun.

Pada ke-4 penelitian mola hidatidosa tidak banyak perbedaan mengenai median usia, usia termuda, dan tertua. Berdasarkan literatur disebutkan bahwa usia rata-rata penderita mola hidatidosa $<35$ tahun, ${ }^{8,9}$ hal ini sesuai dengan ke- 4 penelitian tersebut. Mola hidatidosa biasanya paling banyak terjadi pada wanita usia reproduksi dan usia remaja ( $<20$ tahun), sedangkan premenopause mempunyai risiko lebih tinggi. Wanita usia $>35$ tahun mempunyai risiko $2 \mathrm{x}$ lebih tinggi, sedangkan wanita usia $>40$ tahun mempunyai risiko 5-10x lebih tinggi dibandingkan dengan wanita yang lebih muda. Riwayat melahirkan sebelumnya tidak berhubungan dengan kejadian mola hidatidosa. ${ }^{20}$

Prevalensi hipertiroid (kadar TSHs $<0,3$ $\mathrm{uIU} / \mathrm{mL}$ ) sebesar $83 \%$. Penelitian sebelumnya mendapatkan prevalensi tirotoksikosis pada penderita mola hidatidosa sebagai berikut: Kariadi sebesar 78,8\%, ${ }^{4}$ Riastuti 74,5\%, ${ }^{5}$ serta Soetedjo dan Kariadi 72,4\%. ${ }^{6}$ Ketiga penelitian ini menggunakan batasan untuk tirotoksikosis jika kadar TSHs $<0,1 \mathrm{uIU} / \mathrm{mL}$. Chiniwala dkk. ${ }^{1}$ menyatakan bahwa prevalensi hipertiroid 25$64 \%$, sedangkan Berkowitz dan Goldstein ${ }^{2,3}$ hanya $7 \%$. Hal ini mungkin disebabkan perbedaan kadar hormon HCG; pada penelitian ini didapatkan kadar $\beta \mathrm{HCG}>300.000 \mathrm{uIU} / \mathrm{mL}$ sebanyak 43 kasus $(45 \%), \quad 100.000-300.000$ sebanyak 14 kasus $(15 \%)$, dan $<100.000 \mathrm{uIU} / \mathrm{mL}$ sebanyak 28 kasus (30\%). Berkowitz dan Goldstein ${ }^{9}$ menyatakan bahwa kadar HCG $>100.000$ uIU/ $\mathrm{mL}$ hanya 2 dari 30 penderita mola hidatidosa dan dengan kadar HCG $>300.000 \mathrm{uIU} / \mathrm{mL}$ hanya 1 dari 17 penderita. Angka ini sangat jauh berbeda dari hasil yang didapat pada penelitian ini. Kadar $\beta \mathrm{HCG}$ ini mungkin yang menjadi penyebab tingginya prevalensi hipertiroid pada ke-3 penelitian sebelumnya, termasuk juga pada penelitian ini. Pada Tabel 5 terlihat korelasi signifikan antara kadar TSHs dan kadar $\beta \mathrm{HCG}(\mathrm{r}$ $=-0,294 ; p=0,004)$, artinya semakin tinggi kadar $\beta$ HCG maka kadar TSHs semakin rendah.

Pada uji eksak Fisher didapatkan hubungan yang signifikan $(p<0,05)$ antara frekuensi nadi $\geq 100 \mathrm{kali} / \mathrm{menit}$ dan kadar TSHs $<0,3 \mathrm{uIU} /$ $\mathrm{mL}$ (hipertiroid baik klinis maupun subklinis), sedangkan untuk tinggi fundus uteri dan rumus diskriminan tidak didapatkan hubungan signifikan $(p>0,05)$. Pada penelitian Kariadi ${ }^{4}$ didapatkan bukan hanya frekuensi nadi $\geq 100 \mathrm{kali} / \mathrm{menit}$, tetapi tinggi fundus uteri $\geq 20$ minggu dapat digunakan sebagai faktor penduga tirotoksikosis. 
Hal yang sama ditemukan juga oleh Riastuti, ${ }^{5}$ serta Soetedjo dan Kariadi, ${ }^{6}$ bahwa hanya frekuensi nadi $\geq 100 \mathrm{kali} /$ menit yang mempunyai hubungan signifikan dengan tirotoksikosis.

Kadar $\beta \mathrm{HCG} \geq 100.000 \mathrm{uIU} / \mathrm{mL}$ mempunyai hubungan signifikan $(\mathrm{p}<0,05)$ dengan hipertiroid (kadar TSHs $<0,3 \mathrm{uIU} / \mathrm{mL}$ ). Kariadi ${ }^{4}$ menemukan kadar complete $\mathrm{HCG} \geq 300.000 \mathrm{uIU} / \mathrm{mL}$ merupakan faktor penduga kuat untuk tirotoksikosis pada penderita mola hidatidosa. Hal ini berbeda karena pada penelitian kami yang diukur adalah kadar $\beta$ HCG dengan metode ECLIA, sedangkan penelitian $\mathrm{Kariadi}^{4}$ yang diperiksa adalah kadar complete HCG dengan metode IRMA.

Pada penelitian ini rumus diskriminan dengan uji eksak Fisher mempunyai hubungan signifikan $(\mathrm{p}<0,05)$ dengan hipertiroid (kadar TSHs $<0,3$ $\mathrm{uIU} / \mathrm{mL}$ ) pada penderita mola hidatidosa yang mempunyai frekuensi nadi $<100 \mathrm{kali} /$ menit tanpa melihat tinggi fundus uteri. Pada kelompok mola hidatidosa dengan frekuensi nadi $<100 \mathrm{kali} /$ menit dan tinggi fundus uteri $<20$ minggu, semua (18) kasus mempunyai rumus diskriminan yang positif, sehingga secara statistik tidak ditemukan hubungan signifikan antara rumus diskriminan positif pada kelompok ini dan hipertiroid.

Pada Tabel 5 kita dapat melihat bahwa kadar TSHs secara uji Spearman mempunyai korelasi negatif yang signifikan derajat sedang dengan frekuensi nadi (r: $-0,525 ; \mathrm{p}=0,000)$ dan mempunyai korelasi negatif yang signifikan derajat lemah dengan kadar $\beta H C G$ (r: $-0,294$; $\mathrm{p}=0,004)$. Untuk mencari besarnya korelasi ini maka dilakukan uji regresi linier; didapatkan hanya frekuensi nadi yang mempunyai koefisien signifikan dengan kadar TSHs, dan didapatkan persamaan: $\mathrm{Y}=1,106-0,009 \mathrm{X} ; \mathrm{Y}=$ kadar TSHS ( $\mathrm{uIU} / \mathrm{mL}$ ) dan $\mathrm{X}=$ frekuensi nadi/menit dengan nilai $\mathrm{F}=26,429$ dan tingkat kepercayaan $95 \%$; jadi pada kasus mola hidatidosa dapat diprediksi kadar TSHs berdasarkan frekuensi nadi/menit pada saat penderita datang dan jika ternyata kadar TSHs $<0,3 \mathrm{uIU} / \mathrm{mL}$ dapat didiagnosis hipertiroid, sehingga dapat langsung melakukan terapi hipertiroid sebelum tindakan kuretase tanpa harus menunggu pemeriksaan kadar TSHs terlebih dahulu.

Disimpulkan frekuensi nadi/menit $>100 \mathrm{kali} /$ menit merupakan prediktor untuk hipertiroid (kadar TSHs $<0,3 \mathrm{uIU} / \mathrm{mL}$ ). Pada penderita mola hidatidosa dengan frekuennsi nadi $<100$ kali/ menit maka rumus diskriminan dapat digunakan untuk mendiagnosis adanya hipertiroid.

Pada keadaan emergensi kita dapat memprediksi kadar TSHs dengan rumus: 1,106-0,009 $x$ frekuensi nadi/menit). Rumus ini dapat dipergunakan untuk memprediksi kadar TSHs dari frekuensi nadi/menit pada penderita mola hidatidosa. Apakah rumus ini dapat digunakan untuk mendiagnosis hipertiroid pada penderita mola hidatidosa yang telah dilakukan kuretase atau pada kasus penyakit trofoblastik kehamilan lainnya masih perlu dilakukan penelitian lanjutan.

\section{Daftar Pustaka}

1. Chiniwala NU, Woolf PD, Bruno CP, Kaur S, Spector H, Yacono K. Thyroid storm caused by a partial hydatidiform mole. Thyroid. 2008; 18(4):479-81.

2. Berkowitz RS, Goldstein DP. Current management of gestational trophoblastic diseases. Gynecol Oncol. 2008;1016:1-11.

3. Berkowitz RS, Goldstein DP. Molar pregnancy. N Engl J Med. 2009;360:163945.

4. Kariadi SH. Identifikasi penduga potensial untuk diagnosis tirotoksikosis pada penderita mola hidatidosa (Disertasi). Bandung: Program Pascasarjana Universitas Padjadjaran; 1992.

5. Riastuti M. Nilai faktor penduga dan rumus fungsi diskriminan dalam diagnosis tirotoksikosis pada penderita mola hidatidosa. Diajukan pada Konferensi Kerja PAPDI, Yogyakarta 1999.

6. Soetedjo NNM, Kariadi SHK. Predictive value and discriminant calculation in diagnosis thyrotoxicosis in hydatidiform mole patients. Diajukan pada $8^{\text {th }}$ AOTA Congress. Manila, Philipina 2007.

7. Bloomgarden ZT. Abnormal thyroid function during pregnancy. 2003. (diunduh 23 Maret 2009). Tersedia dari: www.medscape.com/ viewarticle/458428.

8. Garg R, Giuntoli RL. Gestational trophoblastic disease. Dalam: Fortner KB, Szymanski LM, Fox HE, Wallach EE, penyunting. Johns Hopkins manual of gynecology and obstetrics. Edisi ke-3. Philadelphia: Lippincott Williams and Wilkins; 2007. hlm. 527-37.

9. Berkowitz RS, Goldstein DP. Gestational trophoblastic disease. Dalam: Berek JS, penyunting. Berek and Novak's gynecology. Edisi ke-14. Philadelphia: Lippincott Williams and Wilkins; 2007. hlm. 2376-405.

10. Malye RH, Trivedi TH, Padhiyar NN, Moulick ND, Yeolekar ME. ARDS is a case of vesicular mole with secondary hyperthyroidisim. JAPI. 2004;52:992-3.

11. Zivaljevic M, Tesic M, Vujkov T, Rajovic J, Popovic M. Gestational trophoblastic disease. Arch Oncol. 2002;10(2):71-5.

12. Van Trommel NE, Sweep FCGJ, Schijt CPT, Massuger LFAG, Thomas CMG. Diagnosis 
of hydatidiform mole and persistent trophoblastic disease: diagnosis accuracy of total human chorionic gonadotropin (HCG), free HCG $\alpha$ - and $\beta$-subunits, and their ratios. Eur J Endocrinol. 2005;153:565-75.

13. Stenman VH, Tiitinen A, Alfthan H, Valmu L. The classification, function and clinical use of different isoform of HCG. Human Reproduction Update. 2006;12:769-84.

14. Tonacchera M, Ferrarini E, Dimida A, Agretti P, De Marco G, De Servi M. TSH reseptor antibodies do not alter the function of gonadotropin receptors stably expressed in eukaryotic cells. Eur J Endocrinol. 2004;150:381-7.

15. Glinoer D. Thyroid disease during pregnancy. Dalam: Braverman LE, Utiger $\mathrm{RD}$, penyunting. Werner \& Ingbar's the thyroid a fundamental and clinical text. Edisi ke-9. Philadelphia: Lippincott Williams and Wilkins; 2005. hlm. 1086-108.

16. Meister LHF, Hauck PR, Graf H, Carvalho GA. Hyperthyroidism due to secretion of human chorionic gonadotropin in a patient with metastatic choriocarcinoma. Arq Bras Endocrinol Metab. 2005;49(2):319-22.
17. Cole LA, Khanlian SA, Muller CY, Giddings A, Kohorn E, Berkowitz R. Gestational trophoblastic disease: Human chorionic gonadotropin-free- $\beta$-subunit, a reliable marker of placental site trophoblastic tumors. Gynecol Oncol. 2006;102:160-4.

18. Fauci AS, Kasper DL, Longo DL, Braunwald E, Hauser SL, Jameson JL. Disorders of the cardiovascular system. Section 3 . Disorders of rhythm. Chapter 226 The tachyarrhythmias. Dalam: Fauci AS, Longo DC, Braunwald E, Loscalzo J, penyunting. Harrison's principle of internal medicine. Edisi ke-17. Philadelphia: McGraw-Hill's; 2008. hlm. 2345-6.

19. Ross DS. Subclinical thyrotoxicosis. Dalam: Braverman LE, Utiger RD, penyunting. Werner \& Ingbar's the thyroid a fundamental and clinical text. Edisi ke-9. Philadelphia: Lippincott Williams and Wilkins; 2005. hlm. 1079-85.

20. Moore LE, Hernandez E. Hydatidiform mole (diunduh 24 Maret 2009). Tersedia dari: http://emedicine.medscape.com/article/ 254657. 